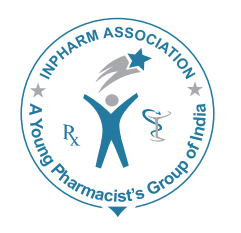

\title{
JVP
}

\section{Pharmacognostic Standardization, Physico- and Phytochemical Evaluation of Amaranthus Spinosus Linn. Root}

\author{
Jhade D, Ahirwar D, Jain R, Sharma NK, Gupta S \\ School of Pharmacy, Chouksey Engineering College, Bilaspur, Chhattisgarh, India \\ Address for correspondence: Mr. Sandeep Gupta; E-mail: sand8483@yahoo.com
}

\begin{abstract}
Amaranthus spinosus Linn. (Amaranthaceae) is found throughout India. This tree species has been of interest to researchers because it is a medicinal plant employed in the Indian traditional system of medicine. Pharmacognostic standardization; physico-and phytochemical evaluation of the roots of Amaranthus spinosus was carried out, to determine its macro-and microscopical characters, and also some of its quantitative standards. Microscopical studies were done by using the trinocular microscope. Total ash, water-soluble ash, acid-insoluble ash, sulfated ash values, and alcohol-and water-soluble extractive values were determined for physico-chemical evaluations. A preliminary phytochemical screening was also done to detect different phytoconstituents. Microscopically, the root showed cork, cortex, stellar region, and calcium oxalate crystals. Powder microscopy showed anamalous secondary growth in between the xylem vessels and Calcium Oxalate crystals in the cortex region. Total ash was approximately three times more than acid insoluble and water soluble ash. The ethanol soluble extractive was approximately the same as the water soluble extractive. Thin Layer Chromatography (TLC) of the Petroleum-ether extract using Benzene : Ethyl acetate $(6: 1)$, showed six spots. In the chloroform extract, using Benzene : Ethyl acetate $(4: 1)$ nine spots were seen, and in the ethanol extract, using Chloroform: Methanol (93:7), only four spots were observed, using lodine vapor as a viewing medium. Phytochemically, the root exhibited terpenes, alkaloids, glycosides, and sugars. These findings might be useful to supplement information with regard to its identification parameters, which are assumed significant in the way of acceptability of herbal drugs, in the present scenario, which lacks regulatory laws to control the quality of herbal drugs.
\end{abstract}

Key words: Amaranthus spinosus Linn., pharmacognostic standardization, physicochemical evaluations

\section{INTRODUCTION}

Amaranthus spinosus Linn. (Amaranthaceae) ${ }^{[1]}$ is an annual herb found throughout India and also in many

\begin{tabular}{|l|l|}
\hline \multicolumn{2}{|c|}{ Access this article online } \\
\hline Quick Response Code: & \multirow{2}{*}{ Website: } \\
\hline & www.jyoungpharm.in \\
& \\
\hline
\end{tabular}

tropical countries. The roots are used as a laxative, as emollient poultice, ${ }^{[1]}$ as antimalarial, ${ }^{[2]}$ antioxidant, ${ }^{[3]}$ antiinflammatory, antimicrobial, and antidiuretic agents, and also in hepatic disorders. ${ }^{[4-6]}$ The water extract of the plant showed significant immunostimulating activity. ${ }^{[7]}$

Pharmacognostic studies have not been reported for the roots of this plant. Therefore, the main aim of the present study is to study the macro, microscopic, and some other pharmacognostic characters and physicochemical standards of the roots of A. spinosus Linn., which could be used to prepare a monograph for the proper identification of the plant. 


\section{MATERIALS AND METHODS}

\section{Plant material}

The plant specimens for the study were collected from the bank of the Arpa river, Bilaspur, (Chhattisgarh, India) $22^{\circ} 06^{\prime} 35.83^{\prime \prime} \mathrm{N}$ and $82^{\circ} 08^{\prime} 06.23^{\prime \prime} \mathrm{E}$, and were positively identified and authenticated by the Botanist Dr. Shiddhamallaya N, Regional Research Institute (Ay.), Central council for research in Ayurveda and Siddha, Ashoka Pillar, Jayanagar, Bangalore. The voucher specimen No. was (RRCBI / mus.5-27), Reference No. (RRI / BNG / SMP / Drug Authentication / 2008-'09 / 959), Dated 28 / 02 / 2009. Care was taken to select healthy fully grown plants with normal organs. The samples of the different organs were cut suitably, removed from the plant, thoroughly washed with water to remove the adherent impurities, and dried in sunlight.

\section{Macroscopical characterization}

Macroscopical studies of the root were carried out using the naked eye, and the shape, color, taste, and odor of roots were determined and reported.

\section{Microscopical characterization}

\section{Sectioning}

Selected samples of the dried root were stored in a solution containing formalin $(5 \mathrm{ml})$, acetic acid $(5 \mathrm{ml})$, and $70 \%$ $\mathrm{v} / \mathrm{v}$ ethyl alcohol (FAA) $(90 \mathrm{ml})$. After 24 hours of fixing, the specimens were dehydrated with a graded series of tertiary-Butyl alcohol as per the method. ${ }^{[8]}$ Infiltration of the specimens was carried out by gradual addition of paraffin wax $\left(50-60^{\circ} \mathrm{C}\right.$ m.p. $)$ until the tertiary-Butyl alcohol solution attained supersaturation. The specimens were casted into paraffin blocks. The paraffin-embedded specimens were sectioned with the help of a Senior Rotary Microtome, RMT-30 (Radical Instruments, India). The thickness of the sections was kept between 10 and $12 \mu \mathrm{m}$. The dewaxing of the sections was carried out as per the procedure described by Johanson. ${ }^{[9]}$ The section was stained with phloroglucinol-hydrochloric acid $(1: 1)$ and mounted in glycerin. A separate section was prepared and stained with iodine solution for the identification of starch grains. Powder [Sieve mesh 60 (Sixty)] of the dried roots was used for the observation of powder microscopical characters. The powdered drug was separately treated with phloroglucinol-hydrochloric acid (1:1) solution, acetic acid, and iodine solution to determine the presence of Sclerenchymatous interfasicular tissue, parenchymatous tissue, and xylem vessels. ${ }^{[10]}$
Photomicrograph

Microscopic descriptions of the selected tissues were supplemented with micrographs. Photographs of different magnifications were taken with Nikon Lab Photo 2 (Two) Microscopic unit. For normal observations, a bright field was used. For the study of crystal, starch grains, and lignified cells, polarized light was employed. As these structures have a birefringent property under polarized light they appear bright against a dark background. ${ }^{[11]}$

\section{Physicochemical evaluations}

Physicochemical parameters of $A$. spinosus root powder were determined ${ }^{[12]}$ and reported as total ash, watersoluble ash, acid-insoluble ash, and sulfated ash values. Alcohol and water-soluble extractive values were determined to find out the amount of water and alcoholsoluble components. The moisture content and $\mathrm{pH}$ was also determined.

\section{Preliminary phytochemical screening}

The coarse root powder of $A$. spinosus (25 g) was subjected to soxhlet for successive solvent extraction. The extract was concentrated and subjected to various chemical tests to detect the presence of different phytoconstituents. ${ }^{[13,14]}$

\section{RESULTS}

\section{Macroscopical study}

The root was long, easily breakable by hand, about 10 to $12 \mathrm{~cm}$ in length, and 0.1 to $0.3 \mathrm{~mm}$ in breadth. The surface was brown in color, but inside it was cream in color. The fractures were slightly fibrous [Figure 1]. It had a slightly sweetish taste and agreeable odor.

\section{Microscopical study}

The transvers section of the root was circular in outline and showed the outer cork, cortex, and stellar regions [Figures 2 and 3]. Abundant clustered crystals of Calcium oxalate were present in the cortex region [Figure 4]. Centrally, the stellar region was present with well-developed xylem and phloem [Figures 2 and 5]. The medullary rays were multiseriate and well-developed. The cork was six-to-eight layered and the cortex was narrow, five-to-seven layered.

One outstanding anatomical peculiarity is the anomalous growth, which is thick in the axis, and takes place by the development of a succession of collateral vascular bundles 


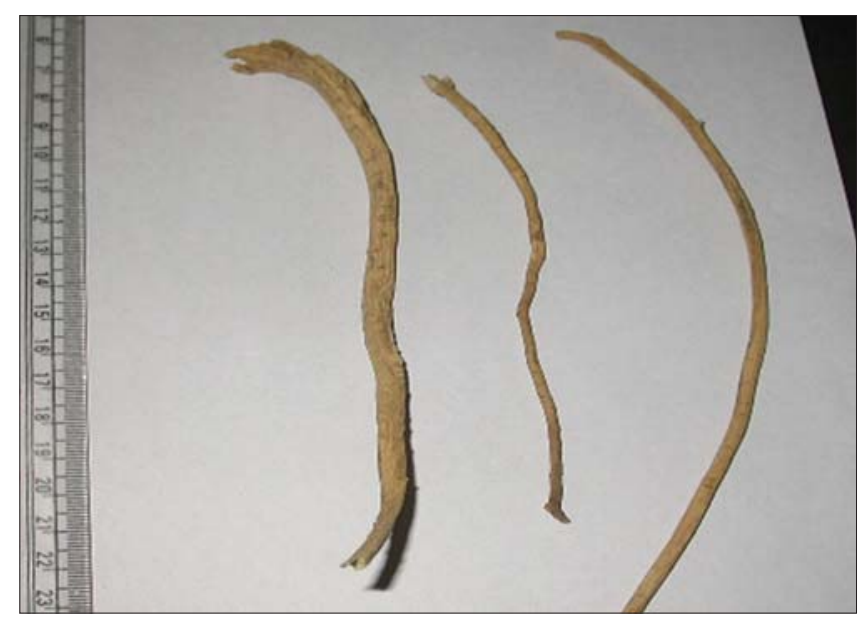

Figure 1: External morphology of the $A$. spinosus root

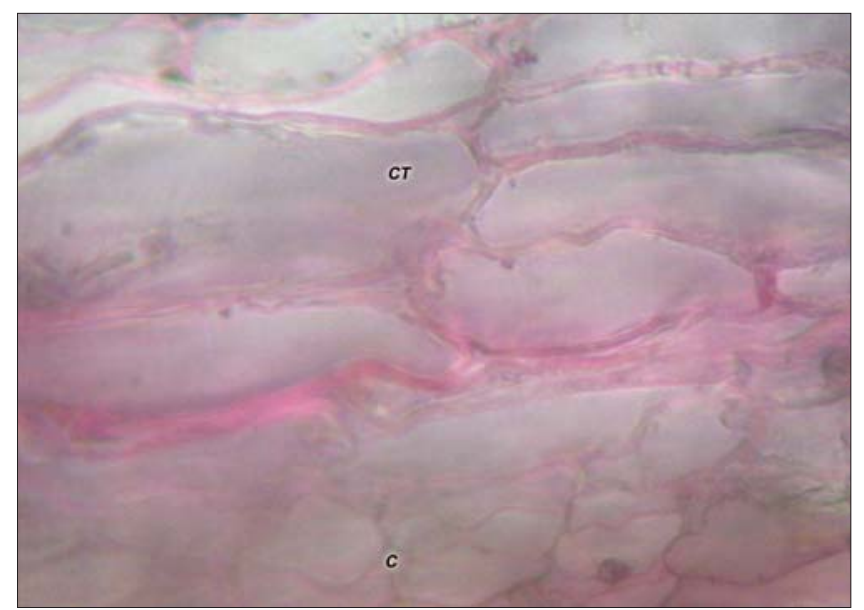

Figure 3: Microscopical view of the cortex and cork, enlarged at $\times 10 \times \times 40$

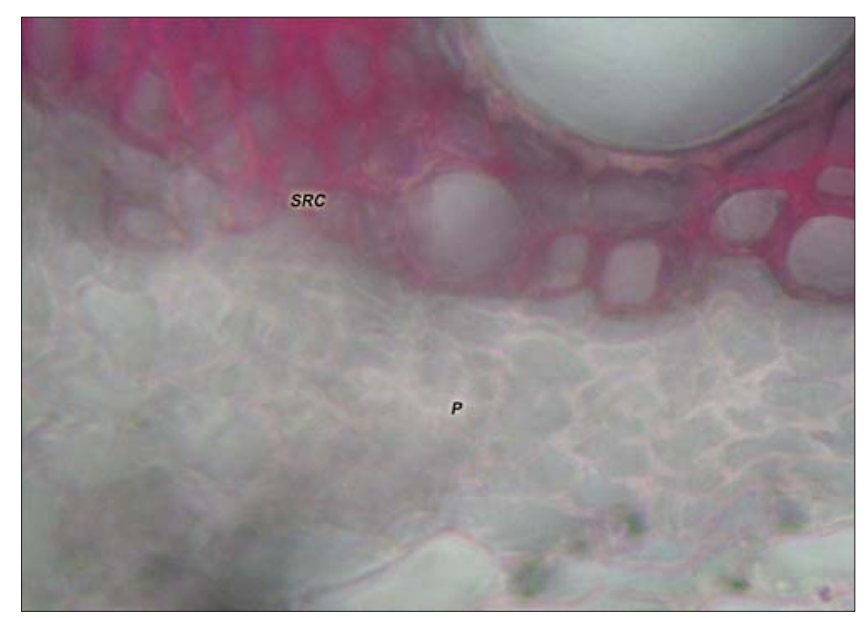

Figure 5: Microscopical view of the Phloem enlarged at $\times 10 \times \times 40$. [SRC: Sclerenchyma, P: Phloem]

from rings or arcs of secondary meristamatic tissue in the pericycle. The bundles are embedded in the parenchymatous ground tissue. One conjunctive tissue, between the bundles,

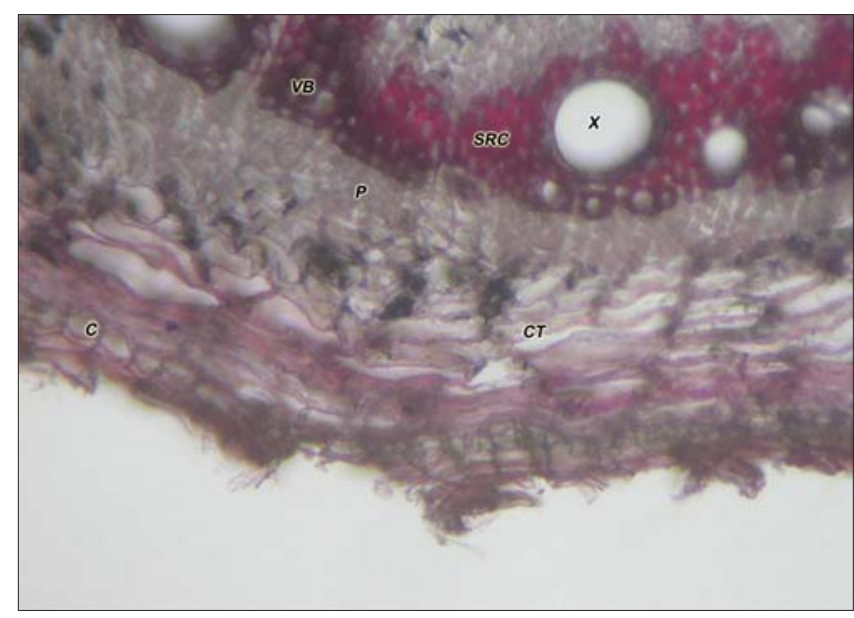

Figure 2: Microscopical view of the T. S. of the $A$. spinosus root at $\times 10 \times \times 40$. [C: Cork, CT: Cortex, X: Xylem, P: Phloem, VB: Vascular bundle, SRC: Sclerenchyma]

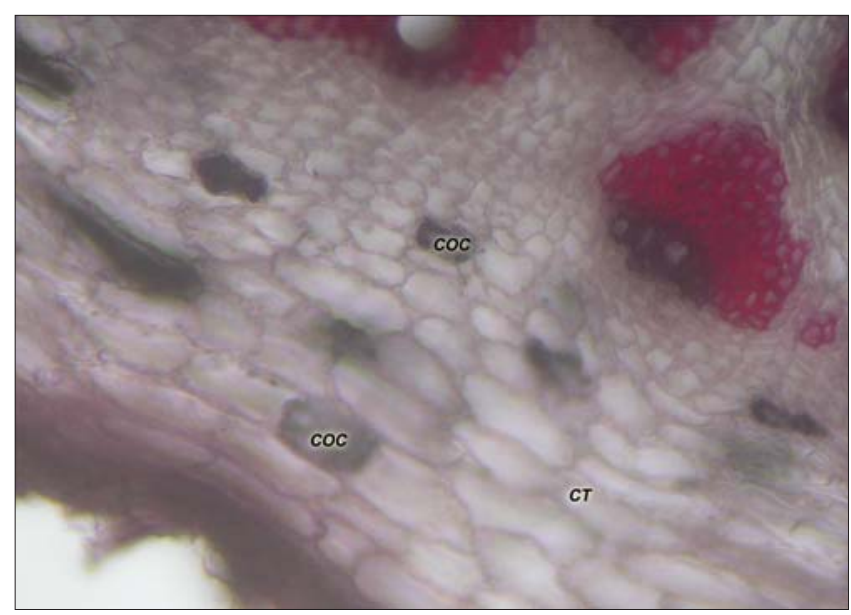

Figure 4: Microscopical view of the cortex with calcium oxalate crystals at $\times 10 \times \times 40$. [COC: Calcium oxalate crystals, CT: Cortex]

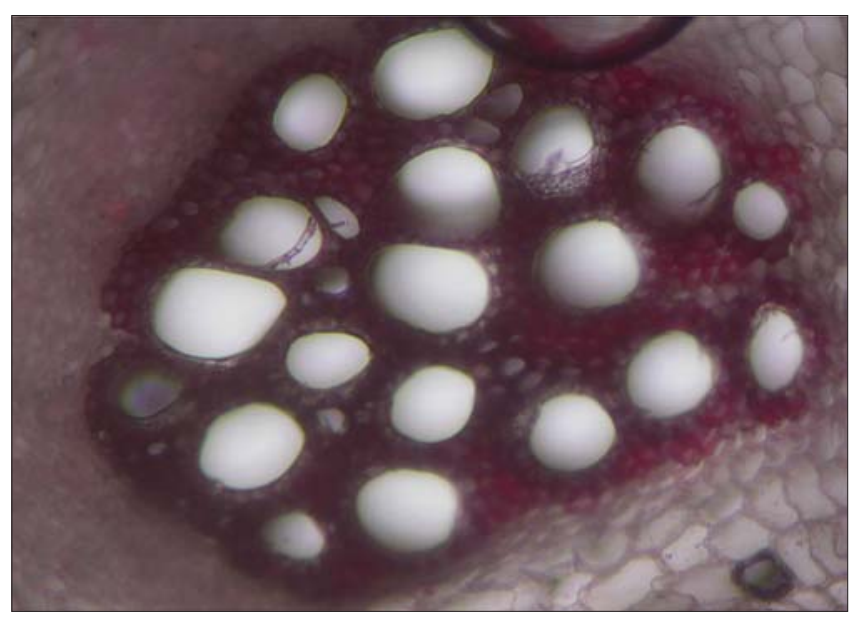

Figure 6: Microscopical view of the vascular bundle, enlarged at $\times 10 \times \times 40$

consists of parenchyma in some species or the other, lignified or unlignified parenchyma. Frequently the ground tissue is wholly lignified in some growth zones [Figure 6]. 


\section{Powder microscopy}

The microscopic study of the powder revealed the presence of an anomalous secondary growth, with sclerenchymatous interfasicular tissue, with concentric zones of parenchymatous tissue. There was a presence of abundant clustered crystals of calcium oxalate in the cortex region. There was a presence of anamalous secondary growth with concentric conjunctive tissue in between the xylem vessels.

\section{Physicochemical parameters}

A. spinosus root powder showed the presence of total ash $6.60 \% \mathrm{w} / \mathrm{w}$, acid-insoluble ash $-2.09 \% \mathrm{w} / \mathrm{w}$, water-soluble ash $-2.44 \% \mathrm{w} / \mathrm{w}$, water-soluble extractive $-5.03 \% \mathrm{w} / \mathrm{w}$, alcohol-soluble extractive $-6.60 \% \mathrm{w} / \mathrm{w}$, moisture content $-2.07 \%$, and $\mathrm{pH}-6.9$ [Table 1].

Preliminary phytochemical studies

Phytochemical analysis showed the presence of terpene in all three extracts. The alcohol extract also showed a positive report for alkaloids, glycosides, and sugars [Table 2]. The TLC of Petroleum - ether $\left(60-80^{\circ} \mathrm{C}\right)$ extract of the drug on Silica gel $60 \mathrm{~F}_{254}$ pre-coated sheets using Benzene : Ethyl acetate $(6: 1)$ showed six spots in Iodine vapor. In the chloroform extract, using Benzene : Ethyl acetate $(4: 1)$, nine spots were seen, and in ethanol extract, using the Chloroform : Methanol (93:7) solvent system, only four spots were observed using the same viewing medium [Table 3].

\section{DISCUSSION}

The macroscopic study of the root indicated that its color, odor, and taste may be an important characteristic feature for identifying the plant. The anatomy of the root was studied by taking a transverse section. The transverse section of the root was circular in outline and showed an outer cork, cortex, and stellar regions. It also showed the presence of abundant clustered crystals of Calcium oxalate in the cortex region and well-developed xylem and phloem in the central stellar region. The medullary rays were multiseriate and welldeveloped.

The powder microscopical examination showed anamalous secondary growth in between the xylem vessels and the presence of abundant clustered crystals of calcium oxalate in the cortex region.
Table 1: Physicochemical analysis of the root of Amaranthus spinosus Linn.

\begin{tabular}{lc}
\hline Physicochemical parameters & Value \\
\hline Total ash & $6.60 \% \mathrm{w} / \mathrm{w}$ \\
Acid insoluble ash & $2.09 \% \mathrm{w} / \mathrm{w}$ \\
Water soluble ash & $2.44 \% \mathrm{w} / \mathrm{w}$ \\
Water soluble extract & $5.03 \% \mathrm{w} / \mathrm{w}$ \\
Ethyl alcohol soluble extract & $6.60 \% \mathrm{w} / \mathrm{w}$ \\
Moisture content & $2.07 \%$ \\
$\mathrm{pH}$ & 6.9 \\
\hline
\end{tabular}

*w/w: weight/weight

Table 2: Phytochemical analysis of Amaranthus spinosus Linn. root

\begin{tabular}{llll}
$\begin{array}{l}\text { Test for } \\
\text { constituent }\end{array}$ & $\begin{array}{l}\text { Petroleum }- \\
\text { ether extract }\end{array}$ & $\begin{array}{l}\text { Chloroform } \\
\text { extract }\end{array}$ & $\begin{array}{l}\text { Ethyl alcohol } \\
\text { extract }\end{array}$ \\
\hline Alkaloid & Negative & Negative & Positive \\
Steroid & Negative & Negative & Negative \\
Terpene & Positive & Positive & Positive \\
Flavanoid & Negative & Negative & Negative \\
Glycoside & Negative & Negative & Positive \\
Sugars & Negative & Negative & Positive \\
Saponin & Negative & Negative & Negative \\
Tannin & Negative & Negative & Negative \\
Colour and & Yellow oily & Green gum & Dark green \\
consistancy & & & solid gum \\
*Positive: present, Negative: absent & &
\end{tabular}

Table 3: Thin layer chromatography pattern of various extracts of Amaranthus spinosus Linn. root

\begin{tabular}{|c|c|c|c|c|}
\hline Extract & Adsorbent & Solvent system & $\begin{array}{l}\text { Viewing } \\
\text { medium }\end{array}$ & $\mathbf{R}_{\mathrm{f} \text {. Values }}$ \\
\hline $\begin{array}{l}\text { Petroleum- } \\
\text { ether } \\
60-80^{\circ} \mathrm{C}\end{array}$ & $\begin{array}{l}\text { Silica gel } 60 \mathrm{~F}_{254} \\
\text { pre-coated sheets }\end{array}$ & $\begin{array}{l}\text { Benzene : Ethyl } \\
\text { acetate }(6: 1)\end{array}$ & $\begin{array}{l}\text { Iodine } \\
\text { vapor }\end{array}$ & $\begin{array}{l}0.02,0.14,0.24 \\
0.36,0.40,0.62\end{array}$ \\
\hline Chloroform & $\begin{array}{l}\text { Silica gel } 60 \mathrm{~F}_{254} \\
\text { pre-coated sheets }\end{array}$ & $\begin{array}{l}\text { Benzene : Ethyl } \\
\text { acetate }(4: 1)\end{array}$ & $\begin{array}{l}\text { Iodine } \\
\text { vapor }\end{array}$ & $\begin{array}{l}0.11,0.18,0.24 \\
0.33,0.42,0.48 \\
0.54,0.67,0.85\end{array}$ \\
\hline Ethanol & $\begin{array}{l}\text { Silica gel } 60 \mathrm{~F}_{254} \\
\text { pre-coated sheets }\end{array}$ & $\begin{array}{l}\text { Chloroform : } \\
\text { Methanol (93: 7) }\end{array}$ & $\begin{array}{l}\text { Iodine } \\
\text { vapor }\end{array}$ & $\begin{array}{c}0.20,0.29,0.37 \\
0.46\end{array}$ \\
\hline
\end{tabular}

Total ash was approximately three times more than acid insoluble and water soluble ash. The ethanol-soluble extractive was approximately the same as the water-soluble extractive.

Phytochemically, the root was found to contain alkaloids, glycosides, terpenes, and sugars. The TLC of the petroleum-ether extract using Benzene : Ethyl acetate $(6: 1)$, which showed six spots. In the chloroform extract, using Benzene : Ethyl acetate ( $4: 1)$, nine spots were seen, and in the ethanol extract, using Chloroform : Methanol (93: 7), only four spots were observed using Iodine vapor as a viewing medium.

The constant physical evaluation of drugs is an important parameter in detecting adulteration or improper handling 
of drugs. The total ash is particularly important in the evaluation, for the purity of the drugs, that is, to identify the presence or absence of foreign inorganic matter such as metallic salts and/or silica. The moisture content of the drug is not too high, thus it can discourage bacterial, fungi or yeast growth, as the general requirement for moisture content in crude drug is not more than $14 \% \mathrm{w} / \mathrm{w} .{ }^{[7]}$ The ash values, extractive values, and moisture content of the roots were determined. The results are depicted in [Table 2]. Pharmacognostic standardization including the physicochemical evaluation in Tables 1 and 2 is meant for identification, authentication, and detection of adulteration, as also for the compilation of quality control standards for crude drugs. ${ }^{[15]}$ As the plant, Amaranthus spinosus Linn. is useful in traditional medicine for the treatment of some ailments, it is important to standardize it for use as a drug.

The pharmacognostic constants for the roots of this plant, the diagnostic microscopic features, and the numerical standards reported in this study can be useful for the compilation of a suitable monograph for its proper identification.

\section{CONCLUSION}

The present study on the pharmacognostic standardization and the physico-and phytochemical evaluation of the Amaranthus spinosus root might be useful to supplement information with regard to its identification parameters, which are assumed significant for the acceptability of herbal drugs in the present scenario, which lacks regulatory laws to control the quality of herbal drugs.

\section{ACKNOWLEDGMENT}

I express my sincere thanks to Dr. Dheeraj Ahirwar, M.Pharm., Ph.D., Principal, School of Pharmacy, Chouksey Engineering College, Bilaspur (C.G.), who took an interest in looking into our research needs, thus providing us with the best available resources.

\section{REFERENCES}

1. Kirtikar KR, Basu BD. Indian Medicinal Plants. $2^{\text {nd }}$ ed. Vol 3. Dehradun, India: International book distributors; 1999. p. 2057-8.

2. Hilou A, Nacoulma OG, Guiguemde TR. In vivo antimalarial activities of extracts from Amaranthus spinosus L. and Boerbaavia erecta L. in mice. J Ethnopharmacol 2006;16:236-40.

3. Amin I, Norazaidah Y, Hainida KI. Antioxidant activity and phenolic content of raw and blanched Amaranthus species. Food Chem 2006;94:47-52.

4. Olajide O, Ogunleye B, Erinle T. Antiinflammatory properties of Amaranthus spinosus leaf extract. Pharm Biol 2004;42:521-5.

5. Stintzing FC, Kammerer D, Schieber A, Adama H, Nacoulma OG, Carle R. Betacyanins and phenolic compounds from Amaranthus spinosus and Boerhaavia erecta L. Z Naturforsch C 2004;59:1-8.

6. Van Dunen MB. Antimicrobial activity of Boerhaavia diffusa L. (Nyctagynaceae). Pharmacopée et Médecine Traditionnelle Africaines 1985;3:23-5.

7. African Pharmacopoeia. General Methods for Analysis. $1^{\text {st }}$ ed. Vol 2. (OAU/ STRC) Lagos; 1986. p. 123.

8. Sass JE. Elements of Botanical Microtechnique. New York: Mc Graw Hill; 1940.

9. Johanson DA. Plant Microtechniques. New York: Mc Graw Hill; 1940.

10. Kokate CK. Practical Pharmacognosy. Delhi: Vallabh Prakashan; 1997.

11. Esau K. Plant Anatomy. New York: John Wiley and Sons; 1964.

12. The Ayurvedic Pharmacopoeia of India. 1999;1:191-2.

13. Khandelwal KR. Practical book of pharmacognosy. Pune, India: Nirali prakashan; 2005.

14. Harborne JB. Phytochemical Methods. London: Chapman and Hall; 1998.

15. Kokate CK, Purohit AP. A text book of pharmacognosy. Pune, India: Nirali Prakashan; 2006.

How to cite this article: Jhade D, Ahirwar D, Jain R, Sharma NK, Gupta S. Pharmacognostic standardization, physico- and phytochemical evaluation of Amaranthus spinosus Linn. root. J Young Pharmacists 2011;3:221-5.

Source of Support: Nil, Conflict of Interest: None declared. 